\author{
Karolina Bressa
}

\title{
Status embrionów ludzkich na tle zdolności patentowej wynalazków biotechnologicznych
}

Wydany 18. 10. 2011 roku przez Trybunał Sprawiedliwości Unii Europejskiej wyrok w sprawie C-34/10 Oliver Brüstle przeciwko Greenpeace eV był pierwszym rozstrzygnięciem stanowczo przesądzającym o zakresie pojęcia „embrionów ludzkich” w myśl Dyrektywy 98/44/WE - a zatem, w konsekwencji, determinującym dopuszczalność patentowania tak zdefiniowanych organizmów. Decyzja Trybunału wywołała kolejną dyskusję w sprawie możliwości patentowania materiału biologicznego pochodzenia ludzkiego, w następstwie której pojawiło się wiele głosów krytycznych podnoszących ryzyko hamowania rozwoju nauki i medycyny. Słusznie jednak wskazuje się w doktrynie, że w obliczu osiągnięć biotechnologii - nauki, której znaczenia dla medycyny czy gospodarki nie sposób podważyć - ustalone w prawie patentowym pojęcia i reguły dotyczące wynalazku jako przedmiotu patentu i kryteriów jego odróżnienia od przedmiotów niepatentowalnych, w tym w szczególności od odkryć, a także sposobu interpretacji przesłanek zdolności patentowej, utraciły swoją jednoznaczność i oczywistość ${ }^{1}$. Ponadto trafną uwagę przedstawił rzecznik generalny Yves Bot w opinii przedłożonej w sprawie C-34/10, wskazując na trudności związane $z$ wydawaniem orzeczeń o niewielkim stopniu trwałości z uwagi na postęp wiedzy w szybko rozwijającej się dziedzinie ${ }^{2}$. Za taką niewątpliwie trzeba uznać jeden $z$ najnowszych nurtów biotechnologii związany z wykorzystaniem i pozyskiwaniem komórek macierzystych z embrionów ludzkich, których istotą jest to, że moga podlegać nieograniczonemu podziałowi. Jednocześnie wskazać należy kwestię budzącą w tym wypadku największe wątpliwości, a mianowicie konflikt pomiędzy przyznaniem ochrony prawnej w postaci patentu na wynalazki biotechnologiczne wykorzystujące embriony ludzkie, co wiąże się z ich wykorzystaniem handlowym i komercyjnym,

1 H. Żakowska-Henzler [w:] System prawa prywatnego, tom 14A, red. R. Skubisz, Warszawa 2012, ss. 266-267.

2 Opinia rzecznika generalnego Y. Bota z dnia 10. 03. 2011 r. w sprawie C-34/10, pkt 48. 
a koniecznością poszanowania ludzkiej godności, człowieczeństwa i określenia stanu początkowego ludzkiego istnienia, co podkreślił Trybunał w orzeczeniu w sprawie Brüstle.

\section{Wyrok w sprawie Brüstle i jego implikacje}

Wniosek o wydanie orzeczenia w trybie prejudycjalnym w sprawie Brüstle dotyczył wykładni art. 6 ust. 2 dyrektywy 98/44/WE Parlamentu Europejskiego i Rady z dnia 6 lipca 1998 roku w sprawie ochrony prawnej wynalazków biotechnologicznych ${ }^{3}$. Jest to pierwszy w Unii Europejskiej akt prawny traktujący ochronę osiągnięć z dziedziny biotechnologii w sposób kompleksowy, obejmujący w szczególności kwestie dotyczące patentowania materiału biologicznego, rozróżniania między wynalazkami biotechnologicznymi a odkryciami, wskazujący wyjątki niepodlegające ochronie patentowej oraz zakres ochrony patentowej wynalazków tego typu. Artykuł 5. ust. 1 dyrektywy 98/44/ WE wyłącza zdolność patentową ciała ludzkiego w różnych stadiach formowania się i rozwoju. $Z$ treści tego przepisu, zgodnie z zasadą ochrony godności i integralności osoby, wynika zatem, że patentowanie embrionów ludzkich (a ściślej: także tych komórek macierzystych istniejących w pierwszej fazie rozwoju embrionu, które mogą rozwinąć się w jednostkę ludzką - komórek totipotentnych - co wynika jednoznacznie już z literalnego brzmienia przepisu) jest niedopuszczalne $z$ uwagi na to, że stanowią one jeden z etapów formowania ludzkiego ciała. Art. 5. ust. 2. dyrektywy przyznaje jednak zdolność patentową takim wynalazkom, które stanowią element wyizolowany z ciała ludzkiego (a jak stwierdził rzecznik generalny Yves Bot, taki status można by przypisać embrionalnym komórkom macierzystym pluripotentnym ${ }^{5}$, niezdolnym do rozwinięcia się w jednostkę ludzką) lub inaczej wytworzony sposobem technicznym. Zgodnie z powyższym, sam embrion nie może być uznany za wynalazek, ale już jego wykorzystywanie w celu otrzymywania z niego danych komórek mogłoby podlegać opatentowaniu, co istotnie budzi moralne wątpliwości. Wydaje się, że rozwiązanie spornej kwestii stanowi właśnie badany w niniejszej sprawie art. 6. ust. 2. lit. c) dyrektywy 98/44/WE uściślający, że zdolności patentowej pozbawione jest wykorzystywanie embrionów ludzkich do celów przemysłowych lub handlowych. Przepis ten wymienia taki sposób wykorzystywania embrionów ludzkich jako przykład wynalazków, których handlowe wykorzystanie byłoby sprzeczne $z$ porządkiem publicznym lub dobrymi obyczajami.

Oliver Brüstle był uprawnionym z patentu na otrzymywanie progenitorowych komórek nerwowych, których transplantacja pozwala na regenerację układu nerwowego i leczenie pewnych chorób - w tym choroby Parkinsona. Istotą jego zgłoszenia paten-

3 Dz. Urz. WE L 213 z 30. 7.1998 r., s. 13.

4 A. Twardowska [w:] Prawo wtasności przemystowej. Komentarz, red. P. Kostański, Warszawa 2014, s. 619.

5 Opinia rzecznika generalnego Y. Bota z dnia 10.03.2011 r. w sprawie C-34/10, pkt 101. 
towego jest fakt, że wspomniane komórki wytwarza się z embrionalnych komórek macierzystych ulegających zniszczeniu w trakcie procesu wytwórczego ulegały. Jednakże fakt destrukcji embrionów ludzkich nie był wyszczególniony w specyfikacji patentowej, gdyż stanowił fazę uprzednią względem procesu objętego ochroną patentową. Zatem w świetle powyżej wspomnianych art. 5 i art. 6 ust. 2 lit. c) dyrektywy - powstało pytanie, jak rozumieć pojęcie embrionów ludzkich. Wątpliwość ta implikuje jednocześnie możliwość wyłączenia tak zdefiniowanych bytów spod przyznania ochrony patentowej.

Trybunał uznał - co trzeba zaznaczyć już na wstępie - że z przedmiotem patentu zdecydowanie należy wiązać ewentualną konieczność uprzedniego unicestwienia embrionu ludzkiego, nawet jeśli działanie to nie jest objęte zgłoszeniem patentowym. Odmówił zatem legalizacji takich działań i opatentowania technologii wymagających wcześniejszego unicestwienia embrionów lub ich wykorzystania jako materiału wyjściowego do osiągnięcia finalnego efektu w postaci wynalazku. Ponadto wyraźnie odwołał się do przeznaczenia i funkcji patentu, który jest instrumentem prawnym stworzonym na potrzeby przemysłu, handlu i wykorzystania komercyjnego. Tym samym nie jest możliwe przyznanie ochrony patentowej embrionom dla celów naukowych, gdyż z tym wiązałoby się automatycznie ich umieszczanie w obszarze komercyjnym. Trybunał podkreślił w ślad za motywem pkt 42. preambuły dyrektywy - że przedmiotem patentu może być jedynie wykorzystywanie embrionów do celów terapeutycznych lub diagnostycznych, które jest dla nich użyteczne ${ }^{6}$.

Co jednak najbardziej znaczące, Trybunał podał następującą definicję:

embrionem ludzkim jest każda komórka jajowa począwszy od stadium jej zapłodnienia, każda niezapłodniona komórka jajowa, w którą wszczepiono jądro komórkowe pochodzące $z$ dojrzałej komórki ludzkiej oraz każda niezapłodniona ludzka komórka jajowa, która została pobudzona do podziału i dalszego rozwoju w drodze partenogenezy.

Tym samym Trybunał bardzo szeroko określił pojęcie embrionu ludzkiego, włączając w nie nie tylko zapłodnione komórki jajowe, ale również niezapłodnione, poddane procesowi dalszego rozwoju, tak jak naturalnie zapłodniona komórka. Równie szerokie wykluczenie spod patentowania tego typu materiału biologicznego uzasadniono potrzebą ochrony godności, która - jak stwierdził rzecznik generalny Bot - jest uznawana za ogólną zasadę prawa unijnego. Wskazuje to dobitnie, że rynek unijny opiera się tak-

6 Cf. pkt 42 dyrektywy 98/44/WE: „Ponadto należy wyłączyć możliwość udzielenia patentu na stosowanie embrionów ludzkich do celów przemysłowych lub handlowych; w żadnym przypadku takie wyłączenie nie ma wpływu na wynalazki służące do celów terapeutycznych lub diagnostycznych, które dotyczą embrionu ludzkiego i są dla niego użyteczne”. 
że na wartościach, które wymagają poszanowania ${ }^{7}$. Należy w tym miejscu odwołać się do stanowiska Komisji Europejskiej, wyrażonego w sprawozdaniu z 14. 07. 2005 roku. Wskazała ona już wówczas - co potwierdził TSUE - że przepisy dyrektywy są klarowne $\mathrm{w}$ odniesieniu do totipotentnych komórek macierzystych, gdyż każda przy spełnieniu niezbędnych warunków może dokonać podziału i z każdej z tych komórek może rozwinąć się jednostka ludzka, a na mocy art. 5 ust. 1 dyrektywy ciało ludzkie w różnym stadium formowania się i rozwoju nie może być wynalazkiem posiadającym zdolność patentową. Jednocześnie Komisja podkreśliła, że:

w przypadku pluripotentnych komórek macierzystych sytuacja jest o wiele bardziej skomplikowana. W świetle wyraźnych rozbieżności, jakie występują obecnie między Państwami Członkowskimi w odniesieniu do dopuszczalności badań związanych z embrionalnymi komórkami macierzystymi, stały i szybki rozwój w tej dziedzinie oraz fakt, że sama Dyrektywa przyznaje Państwom Członkowskim możliwość odmowy patentu na podstawie klauzuli porządku publicznego lub moralności na mocy art. 6 ust. 1, Komisja uważa, że przedwczesne jest dalsze definiowanie lub harmonizacja w tej dziedzinie. ${ }^{8}$

Należy zatem wyraźnie stwierdzić, że choć Trybunał wskazał pośrednio, że skoro do otrzymania danego wynalazku - wykorzystującego komórki macierzyste pluripotentne konieczne jest uprzednie unicestwienie embrionu (nawet niewskazane w specyfikacji patentowej, co ma miejsce w przedmiotowej sprawie), nie można udzielić takiemu wynalazkowi ochrony patentowej, uchylił się od określenia statusu pluripotentnych komórek macierzystych, wskazując, że to do sądu krajowego należy ustalenie, czy w świetle rozwoju nauki komórka macierzysta, która została pozyskana z embrionu ludzkiego w stadium blastocysty, stanowi „embrion ludzki”. Nie wypowiedział się więc wprost w kwestii, czy za embrion ludzki uznaje stadium blastocysty, ale powyższe wynika z samej przyjętej przez niego definicji embrionu, zaliczającej do tego pojęcia wcześniejsze stadia rozwoju komórkowego. Ponadto Trybunał nie rozstrzygnął ostatecznie o dopuszczalności patentowania wynalazków związanych z wykorzystaniem pluripotentnych komórek macierzystych w przypadku, gdyby ochrona patentowa na ich wykorzystanie miała zostać przyznana bez konieczności uprzedniego unicestwienia embrionu (co zapewne jest bądź będzie możliwe w obliczu szybko postępującego rozwoju biotechnologii). Wyraźne stanowisko w tej kwestii zajął natomiast rzecznik generalny Bot, wskazując, że pojedyncza komórka pluripotentna sama nie może być uznana za embrion, gdyż została pobrana

7 Opinia rzecznika generalnego Y. Bota z dnia 10. 03. 2011 r. w sprawie C-34/10, pkt 46.

8 Sprawozdanie Komisji dla Rady i Parlamentu Europejskiego, Rozwój i wpływ prawa patentowego w dziedzinie biotechnologii i inżynierii genetycznej, Bruksela 14.07.2005 r. 
w określonym stadium rozwoju embrionu i nie jest zdolna do wznowienia tego rozwoju9 Jednocześnie w jego opinii wynalazki dotyczące komórek macierzystych pluripotentnych mogą mieć zdolność patentową, o ile ich pobieranie nie szkodzi embrionowi, a zatem nie powoduje unicestwienia bądź uszkodzenia ciała ludzkiego w stadium rozwoju $\mathrm{z}$ chwili pobierania ${ }^{10}$.

\section{Sprawa C-364/13 - opinia rzecznika generalnego i wyrok TSUE}

W świetle powyższych uwag oczywistym jest, że Trybunał pozostawił pewien zakres nieokreśloności co do rozumienia pojęcia „embrion ludzki”, szczególnie zważywszy na fakt, iż przyznał sądom krajowym kompetencje do określenia, czy w świetle rozwoju nauki, komórki macierzyste pozyskane $\mathrm{z}$ embrionów ludzkich w stadium blastocysty wchodzą w jego zakres. Sądy krajowe mają nadto pewną swobodę przyznaną w oparciu o art. 6. ust.1. dyrektywy, uprawniający do uznania za niemające zdolności patentowej takich wynalazków, których handlowe wykorzystanie byłoby sprzeczne z porządkiem publicznym lub dobrymi obyczajami. Już sam Bundesgerichtshof (niemiecki sąd federalny orzekający w sprawie Brüstle) po uzyskaniu orzeczenia w trybie prejudycjalnym wykluczył uznanie pewnych nieżywotnych organizmów uzyskanych z oocytów zapłodnionych in vitro za embriony w świetle wyroku Trybunału, gdyż nie są one w stanie zainicjować przebiegu formowania się organizmu człowieka ${ }^{11}$. Tym samym uznać należy, że wyrok w sprawie Brüstle nie rozstrzygnął definitywnie o przyjęciu jednolitego rozumienia pojęcia embrionów ludzkich, co miało być podstawą wydanego orzeczenia ${ }^{12}$.

Ponadto Trybunał w sprawie Brüstle wskazał niejako, że analizy dopuszczalności uznania danego bytu za embrion ludzki należy dokonywać, bacząc na fakt, czy może on zapoczątkować proces rozwoju jednostki ludzkiej ${ }^{13}$. Taki właśnie argument został podniesiony w sprawie C-364/13 International Stem Cell Corporation przeciwko Comptroller General of Patents, w której Trybunał badał, czy wnioski o rejestrację patentów dotyczące aktywacji oocytów w drodze partenogenezy odnoszą się do wykorzystania embrionów ludzkich w rozumieniu dyrektywy 98/44/WE. Wnioskodawca w sprawie C-364/13 ubiegał się o rejestrację dwóch krajowych patentów. Pierwszy wniosek dotyczył partenogenetycznej aktywacji oocytów w procesie uzyskiwania ludzkich zarodkowych komórek macierzystych i zastrzegał metody otrzymywania pluripotentnych ludzkich komórek macierzystych $\mathrm{z}$ aktywowanych partenogenetycznie oocytów i linii komórek

\footnotetext{
9 Opinia rzecznika generalnego Y. Bota, 10.03.2011 r. w sprawie C-34/10, pkt. 98 i 100.

10 Ibidem, pkt. 103.

11 Wyrok Niemieckiego Sądu Federalnego (BGH) z dnia 27.11. 2012 r., X ZR 58/07.

12 Wyrok Trybunału z dnia 18. 10. 2011 r. w sprawie C-34/10, Olivier Brustle vs. Greenpeace eV, pkt. 26 i 28.

13 Ibidem, pkt. 36 i 37.
} 
macierzystych uzyskiwanych zgodnie z zastrzeżonymi metodami. Natomiast w drugim wnosił on o przyznanie ochrony patentowej metodom uzyskiwania sztucznej rogówki lub tworzących ją tkanek z wykorzystaniem metod izolacji pluripotentnych komórek macierzystych z partenogenetycznie aktywowanych oocytów. Wnioskodawca zwrócił się o objęcie ochroną patentową procesu wykorzystującego niezapłodnione ludzkie komórki jajowe pobudzone do podziału i dalszego rozwoju w drodze partenogenezy (partenoty), które Trybunał w sprawie Brüstle jasno sklasyfikował jako wchodzące w zakres definicji „embrionów ludzkich”, a zatem niemające zdolności patentowej. Jak wskazał jednak rzecznik generalny w sprawie C-364/13, sentencję tamtego wyroku trzeba interpretować w zgodzie z uzasadnieniem, jakie doprowadziło do takiego rozstrzygnięcia ${ }^{14}$. Odwołał się on do kluczowego kryterium przyjętego przez Trybunał w sprawie Brüstle - zdolności do zapoczątkowania procesu rozwoju jednostki ludzkiej - wskazując, że implikacją tego przy rozstrzyganiu, czy niezapłodniona komórka jajowa jest embrionem, winna być okoliczność wrodzonej zdolności komórki do rozwinięcia się w jednostkę ludzką. Stanowisko rzecznika generalnego w całości zaaprobował Trybunał w wyroku w sprawie C-364/13, podkreślając, że zdolność do zapoczątkowania procesu rozwoju jednostki ludzkiej należy rozumieć jako posiadanie przez nią wrodzonej zdolności rozwinięcia się $\mathrm{w}$ organizm ludzki ${ }^{15}$. W konsekwencji Trybunał zgodził się z poglądem rzecznika generalnego, że należałoby odmówić partenotom przymiotu embrionów ludzkich z uwagi na fakt, że - jak wynika z obecnego stanu wiedzy - zawierają one jedynie komórki pluripotentne, niezdolne do wykształcenia bytów ludzkich. Rzecznik generalny podkreślił, że takie komórki jajowe pozbawione są ojcowskiego DNA, co sprawia, iż mogą rozwinąć się do stadium blastocysty, ale nie są w stanie zakończyć rozwoju zarodkowego, gdyż komórki partenoty na żadnym etapie podziału nie są totipotentne ${ }^{16}$.

Jednocześnie rzecznik generalny wskazał, że nawet gdyby uznać, iż partenoty nie wchodzą w zakres pojęcia embrionu ludzkiego, państwom członkowskim z mocy art. 6. ust. 1. dyrektywy przysługuje uprawnienie do odmówienia przyznania ochrony patentowej na wykorzystanie partenot do celów przemysłowych i handlowych z racji sprzeczności eksploatacji takich wynalazków z porząakiem publicznym lub dobrymi obyczajami. $Z$ takiego instrumentu zapewne skorzystałaby Polska, która jako jedyna spośród państw członkowskich zgłaszających uwagi na piśmie, zajęła stanowisko zakwestionowane następnie w opinii rzecznika ${ }^{17}$. Wątpliwości Rzeczypospolitej skupiły się na wyrażeniu „mogą zapoczątkować proces rozwoju jednostki ludzkiej”, dotyczyły pytania, czy sfor-

14 Opinia rzecznika generalnego Pedra Cruza Villalona, 17. 07.2014 r.w sprawie C-364/13, pkt. 63. 15 Wyrok Trybunału z dnia 18.12.2014 r. w sprawie C-364/13, International Stem Cell Corporation vs. Comptroller General of Patents, Design and Trade Marks, pkt 27 i 28.

16 Opinia rzecznika generalnego Pedra Cruza Villalona, 17. 07. 2014 r. w sprawie C-364/13, pkt. 57.

17 Uwagi na piśmie Rzeczypospolitej Polskiej, przedkładane na podstawie art. 23 Statutu Trybunału Sprawiedliwości w postępowaniu o wydanie orzeczenia wstępnego w sprawie C-364/13, Warszawa 9.10.2013 r. 
mułowanie to oznacza rozpoczęcie procesu, który powinien mieć zdolność do doprowadzenia do powstania istoty ludzkiej, czy obejmuje także rozpoczęcie procesu rozwoju, pomimo że proces ten nie może zostać ukończony, przez co nie może prowadzić do powstania jednostki ludzkiej. Polska stoi zatem na stanowisku, że wynalazki oparte na niezapłodnionych ludzkich komórkach pobudzonych do podziału i dalszego rozwoju w drodze partenogenezy nie mogą być patentowane, ponieważ posiadają potencjał zapoczątkowania proces rozwoju jednostki ludzkiej, tak jak embrion powstały w wyniku zapłodnienia komórki jajowej. Zgodnie z zapatrywaniem Polski partenogenicznie aktywowane oocyty niewątpliwie rozpoczynają proces podziałów i różnicowania w taki sam sposób, jak zapłodnione oocyty, z których powstał człowiek. Bezwzględnie podkreślono zatem, że na gruncie dyrektywy 98/44/WE ochrona przed stworzeniem monopolu patentowego przyznawana jest całemu organizmowi ludzkiemu już od pierwszej fazy jego rozwoju niezależnie od perspektywy i możliwości ukończenia procesu.

\section{Patentowanie embrionów ludzkich - Europa a sytuacja w państwach pozaeuropejskich}

W wyroku w sprawie Brüstle TSUE wskazał, że brak określenia przez Trybunał jednolitej definicji pojęcia embrionu ludzkiego stwarzałby zagrożenie, że twórcy wynalazków biotechnologicznych je wykorzystujących byliby skłonni do występowania $\mathrm{z}$ wnioskiem o ich opatentowanie w tych państwach członkowskich, w których funkcjonowałaby najwęższa koncepcja definicji ${ }^{18 .}$ Niedopuszczalność opatentowania identycznych wynalazków w krajach, które przyjęłyby szerszą definicję embrionu, wynikałaby z nieprzyznawania w tych państwach członkowskich zdolności patentowej wynalazkom dotyczącym stosowania embrionów ludzkich do celów przemysłowych lub handlowych.

W przypadku wynalazków biotechnologicznych, w tym głównie wykorzystujących materiały biologiczne pochodzenia ludzkiego, bardzo ważkie kwestie etyczne ściśle wiążą się z nieodłącznymi dla pojęcia patentu zagadnieniami gospodarczymi i technologicznymi. Zdolność tworzenia różnych tkanek przez ludzkie komórki embrionalne, w tym także ich wykorzystanie do odtwarzania uszkodzonych tkanek czy narządów, dała możliwość znalezienia metod leczenia dotąd nieuleczalnych schorzeń. Przykładowo, wynalazek Brüstlego pozwala na wyeliminowanie w szczególności problemu technicznego związanego z wytwarzaniem praktycznie nieograniczonej ilości komórek progenitorowych izolowanych i oczyszczonych, które mogą być wykorzystywane do terapii wad układu nerwowego ${ }^{19}$. Zatem ważyć należy tutaj dwie wartości - możliwość komercyjne-

18 Wyrok Trybunału z dnia 18. 10. 2011 r. w sprawie C-34/10, Olivier Brustle vs. Greenpeace eV, pkt. 28.

19 Ibidem, pkt. 18. 
go wykorzystania takich wynalazków, czerpania z nich zysku i inne względy finansowe oraz postęp naukowy i możliwość rozwoju w leczeniu poważnych chorób.

Europejskie stanowisko względem dopuszczalności patentowania wynalazków wykorzystujących embriony ludzkie jest konsekwentne i sprzeciwia się takim praktykom. Kluczowe znaczenie ma decyzja Rozszerzonej Komisji Odwoławczej Europejskiego Urzędu Patentowego (dalej: Rozszerzona Komisja EUP) z dnia 25.11. 2008 r. ${ }^{20}$, na mocy której oddalone zostało odwołanie Wisconsin Alumni Research Foundation dotyczące odmowy opatentowania wynalazku - produktu - linii ludzkich embrionalnych komórek macierzystych (buman embronic stem cell cultures). Uprzednio jednostka ta uzyskała dla wspomnianego wynalazku ochronę patentową w 2001 roku przyznaną przez Urząd Patentów i Znaków Towarowych USA. Obejmowała ona proces izolacji, hodowli oraz produkt - linie komórkowe pochodzące od naczelnych ${ }^{21}$. W decyzji tej wskazano - co następnie zostało podkreślone w wyroku TSUE w sprawie Brüstle - że niedopuszczalne jest opatentowanie wynalazku, który wymaga wcześniejszego unicestwienia embrionu, nawet jeśli fakt ten nie jest ujawniony w zgłoszeniu patentowym. Rozszerzona Komisja EUP podkreśliła, że wynalazek taki - wykorzystujący embriony - musi być kwalifikowany jako sprzeczny z porządkiem publicznym (ordre public) w myśl art. 53 (a) Konwencji o udzielaniu patentów europejskich ${ }^{22}$ (dalej: KPE) i zasady 28 (c) Regulaminu wykonawczego ${ }^{23}$. We wnioskach podmiotów niezależnych od toczącego postępowania reprezentowano poglądy, że oczywistą intencją prawodawcy w Konwencji było zakazanie komercyjnego wykorzystania embrionów, niezależnie nawet od powszechnie uznawanych względów moralnych i etycznych ${ }^{24}$. Rozszerzona Komisja EUP nie uznała za słuszne argumentów wnioskodawcy, który wskazywał, że w przypadku określonego w tej sprawie użycia embrionu nie dochodzi w rzeczywistości do jego zastosowania w celach przemysłowych bądź handlowych i nie ma się tu do czynienia z komercyjnym wykorzystaniem samych embrionów, a dopiero produktów z nich otrzymanych ${ }^{25}$. Wnioskodawca jednocześnie podkreślał, że jeśli akt prawny zakazywałby patentowania produktów otrzymanych z embrionów, zawierałby wprost takie postanowienie, a nie jedynie zapis o niedopuszczalności wykorzystywania embrionów ludzkich do celów przemysłowych bądź handlowych ${ }^{26}$. Rozszerzona Komisja EUP zajęła stanowisko, że już sam proces wytwarzania finalnego produktu związany jest z jego komercyjnym bądź przemysło-

20 Decyzja Rozszerzonej Komisji Odwoławczej EUP z dnia 25.11. 2008 r. w sprawie G 2/06 Use of embryos/WARF; tytuł wynalazku: Primate Embryonic Stem Cells; wnioskodawca: Wisconsin Alumni Research Foundation.

21 A. Twardowska, op. cit., s. 623.

22 Dz. U. z 2004 r. nr 79, poz. 737 ze zm.

23 Decyzja Rozszerzonej Komisji Odwoławczej EUP z dnia 25.11.2008 r., odpowiedź na pytanie 2, s. 30.

24 Ibidem, pkt VIII, s. 12.

25 Ibidem, pkt VI, ss. 6-7.

26 Ibidem, pkt VI, s. 7. 
wym zastosowaniem, a użycie embrionów ma tu znaczenie integralne i konieczne ${ }^{27}$. Jednocześnie wyraźnie zaznaczyła, że nie rozstrzyga o kwestii patentowalności samych ludzkich embrionalnych komórek macierzystych, a jedynie takich, których otrzymanie wymaga uprzedniego unicestwienia embrionów ${ }^{28}$. Powyższe stanowisko zostało powtórzone w decyzji T 522/04 Stem cells/California, potwierdzającej, że skoro pierwotne zgłoszenie patentowe nie wskazuje, jakoby nerwowe komórki macierzyste (mammalian multipotent neural stem cells) mogły zostać otrzymane w inny sposób niż z wykorzystaniem embrionów ludzkich, należy przyjąć, że zostają one otrzymane wyłącznie w sposób wymagający ich unicestwienia, co skutkuje zakazem patentowania takich wynalazków w myśl art. 53 (a) KPE i zasady 28 (c) Regulaminu wykonawczego ${ }^{29}$.

Tymczasem w Japonii czy Stanach Zjednoczonych prowadzone prace naukowe i wyniki badań dotyczące pozyskiwania komórek macierzystych pluripotentnych z dojrzałych komórek ludzkich pobieranych od osoby dorosłej objęte są następczą ochroną patentową. W USA, przeciwnie niż w Europie, wątpliwości natury etycznej co do zastosowania rezultatów rozwoju biotechnologii nie wywołują wprost implikacji na gruncie prawa patentowego ${ }^{30}$. W systemie prawnym USA uprawnienie do odmowy przyznania patentu bada się względem przesłanki użyteczności (utility) wynalazku, choć podkreśla się, że mimo braku wprost wysłowionych wymagań zgodności udzielenia patentu z zasadami moralności, Urząd Patentowy USA w wielu decyzjach brał też te kwestie pod rozwagę ${ }^{31}$. Natomiast dla Europy charakterystyczne jest rozwiązanie (przyjmowane na mocy ustawodawstw państw członkowskich, dyrektywy 98/44/WE i KPE) zakazujące patentowania wynalazków, których wykorzystanie sprzeczne jest z zasadami moralności bądź porządku publicznego.

Badania nad komórkami macierzystymi poza Europą gwałtownie rozwinęły się od momentu uzyskania pierwszej linii ludzkich komórek macierzystych w 1998 roku (dokonał tego dr James Thomson z Uniwersytetu Wiscosin, wynalazkowi EUP odmówił przyznania ochrony patentowej we wskazanej powyżej sprawie G 2/06 - Use of embryos/WARF) ${ }^{32}$. Debata na ten temat stała się bardziej powszechna po 2004 roku, gdy koreańscy badacze ogłosili wyniki eksperymentów prowadzących do rozwinięcia linii komórkowej pluripotencjalnych komórek macierzystych przy użyciu techniki „klonowania terapeutycznego". W jej ramach wytwarza się komórki o tej samej informacji genetycznej, co dany pacjent, i używa do leczenia chorób tego pacjenta, unikając przede wszystkim

27 Ibidem, pkt 25, s. 25.

28 Ibidem, pkt 35, s. 29.

29 Decyzja Komisji Odwoławczej EUP z dnia 28. 05. 2009 r. w sprawie T 522/04 Stem cells/ California, pkt 7, s. 8.

30 H. Żakowska-Henzler, Wynalazek biotechnologiczny. Przedmiot patentu, Warszawa 2006, s. $14-15$

31 Ibidem, s. 242.

32 A. Twardowska, op. cit., s. 623. 
ryzyka ich odrzucenia przez system immunologiczny ${ }^{33}$. Odmowy przyznawania zdolności patentowej takim procesom w Europie mogą mieć negatywny wpływ na prowadzenie badań tego typu. Skłania to specjalistów od wyjazdu do krajów pozaeuropejskich w celu prowadzenia działalności badawczej i naukowej. Wobec tego, że w USA czy Japonii znacznie łatwiej jest uzyskać patent na rozwiązania biotechnologiczne niż w Europie, to tam przeniesiono inwestycje i tam kierowane są środki finansowe od dużych przedsiębiorców na badania w przemyśle biotechnologicznym ${ }^{34}$. Z drugiej strony, stanowisko europejskie - TSUE i Europejskiego Urzędu Patentowego - wyraźnie określa granice dopuszczalności patentowania, sprzeciwiając się twierdzeniu, jakoby „wszystko, co pod słońcem stworzył człowiek, mogło podlegać patentowaniu”, jak z kolei wypowiedział się Sąd Najwyższy Stanów Zjednoczonych, rozpatrując wniosek Chakrabarty ${ }^{35}$.

\section{SUMMARY}

\section{The status of the human embryo in the context of the patentability of biotechnological inventions}

This article presents an overview of the issues surrounding the patenting of inventions concerning the use of the human body, the status of the human embryo and the admissibility of patenting human embryos. In his analysis, the author refers to the provisions of directive 98/44/EC of the European Parliament and of the Council from the 6th July 1998 on the legal protection of biotechnological inventions, which is the main European Union legal act on patenting biological material. Issues discussed in this article refer to article 5 of the above-mentioned directive, according to which the human body, at the various stages of its formation and development, cannot constitute a patentable invention.

KeYwords: human embryo, pluripotent cells, patents, directive 98/44/WE, case C-34/10 Oliver Brustle vs Greenpeace eV, case C-364/13 International Stem Cell Corporation vs Comptroller General of Patents

33 Sprawozdanie Komisji dla Rady i Parlamentu Europejskiego, Rozwój i wpływ prawa patentowego w dziedzinie biotechnologii i inżynierii genetycznej, Bruksela 14. 07. 2005 r.

34 H. Żakowska, O. Henzler, op. cit., ss. 15-16.

35447 U.S. 303, 206 USPQ 193 (1980); w orzeczeniu tym stwierdzono dopuszczalność udzielenia patentu na wynalazek, jakiego przedmiotem jest genetycznie zmodyfikowany mikroorganizm, który poprzez wszczepienie weń obcego genu nabrał zdolności niszczenia węglowodorów. 